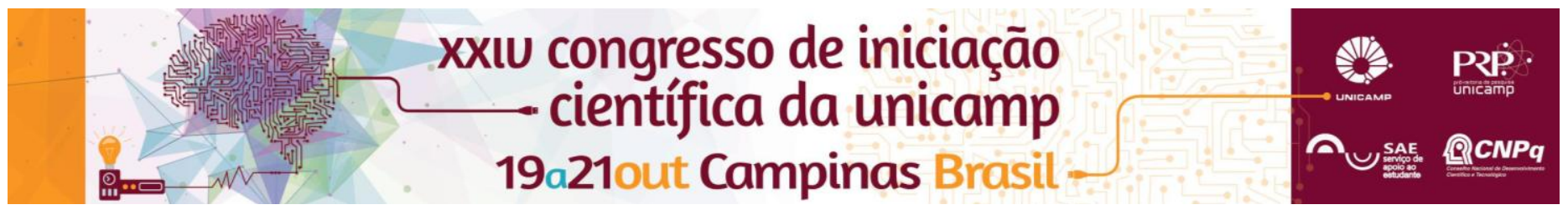

\title{
Montagem e Teste de Dispositivo para Movimentos Forçados em Modelos de Tubo para Captação de Água Fria de Resfriamento em Navio para Produção de Petróleo e Gás
}

\section{Yuri H. G. Kachio*,Yan C. Silveira*,Victor H. T. Correr, Celso Morooka, Catharine Martins, Caio Trigo}

\section{Resumo}

Nesta pesquisa, estudou-se o comportamento dinâmico de um tubo captador de água fria devido aos movimentos da plataforma flutuante sob ação das ondas do mar. Para esse finalidade, realizou-se um teste em escala reduzida em laboratório, colocando-se um modelo do tubo no interior de um tanque de água, conectando a sua extremidade superior a um motor, para simular os movimentos da plataforma.

\section{Palavras-chave:}

Plataforma Flutuante, Movimento, Tubo Captador de Água.

\section{Introdução}

O petróleo é um fluido viscoso, de origem orgânica, e constituído principalmente de hidrocarbonetos. Plataformas flutuantes são unidades encarregadas da extração e armazenamento do petróleo produzido no reservatório. Estas plataformas possuem vários equipamentos que garantem o processamento primário do petróleo na superfície, e para o resfriamento destes equipamentos pode se utilizar a água fria captada do mar através de um tubo vertical suspenso da plataforma flutuante.

Como parte do estudo acompanhou-se a montagem e a realização de testes com modelo do tubo, em escala reduzida, acoplado a um motor. Estes testes foram realizados no interior de um tanque, nas condições com e sem água (Figura 1). Com o motor foi possível simular os movimentos da plataforma, monitorando-se as reações no tubo (vibrações) e verificando o possível efeito de ressonância das vibrações do tubo, o que pode diminuir a sua vida útil.

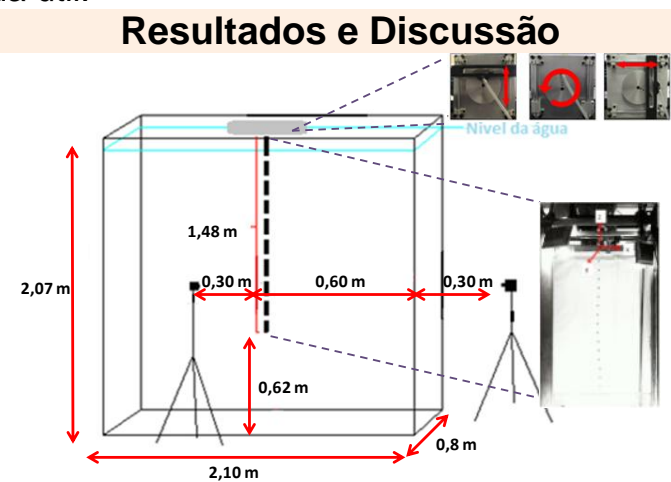

Figura 1. Modelo do tubo captador no interior do tanque.

Ao longo do tubo foram colocados pontos de identificação com fita isolante, e gravados imagens do experimento para a posterior análise. Dados coletados ao longo do comprimento do tubo foram tratados para obter o deslocamento, a diferentes frequências de rotação do motor, particularmente, para as frequências próximas à vibração natural do tubo (Tabela 1).

Tabela 1. Frequências naturais do tubo.

\begin{tabular}{|c|c|c|c|}
\hline & \multicolumn{3}{|c|}{ Frequências naturais $\mathbf{( H z )}$} \\
\hline Ar & 0,49 & 1,14 & 1,89 \\
\hline Água & 0,28 & 0,79 & 2,00 \\
\hline
\end{tabular}

A continuação a Figura 2 apresenta as amplitudes máximas do movimento do tubo.
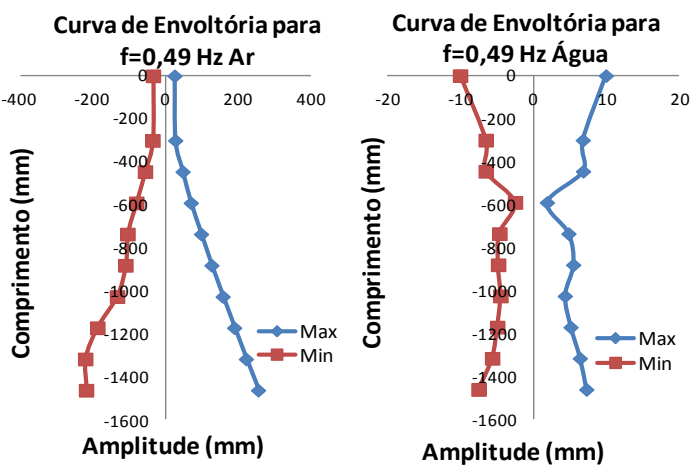

(a)
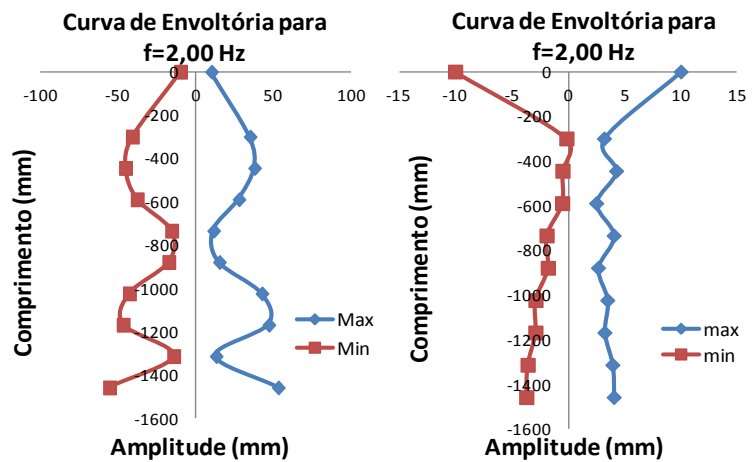

(b)

Figura 2. Envoltória de máximas amplitudes do tubo para o tanque sem água (esquerda) e com água (direita).

(a) $f=0,49 \mathrm{~Hz} ;($ b) $f=2,00 \mathrm{~Hz}$.

\section{Conclusões}

O tubo sofre maiores amplitudes de oscilação quando movimentos são forçados no seu topo, em frequências próximas à suas frequências naturais, tanto no caso do tanque sem água, como com água (Figs. 2). O efeito do amortecimento da água provoca uma diminuição na amplitude máxima de vibração do tubo, o que favorece a conservação da vida útil do tubo.

\section{Agradecimentos}

Os autores agradecem a CNPq e a Pró-reitoria de pesquisa da Unicamp.

THOMAS, "Fundamentos de Engenharia do Petróleo", Rio de Janeiro, 2004. 